\title{
Sosyal Bir Sorun Alanı Olarak Yaşlı Yoksulluğunun İncelenmesi
}

\author{
Gizem Karasoya, b
}

\section{Özet}

Yoksulluk geçmişten günümüze tüm toplumları etkileyen bir sorun olmuştur. Çeşitli toplumsal gruplarda yaşanabilen yoksulluk özellikle sosyal hizmetin odak noktasında olan yaşlı, engelli, kadın, çocuk gibi dezavantajlı grupları daha derinden etkilemektedir. Yaşlılar yoksulluktan etkilenen önemli bir risk grubunu oluşturmaktadır ve yoksulluğun çeşitli görünümlerini deneyimlemektedir. Yoksullukla mücadelede önde gelen akademik disiplinlerden biri de sosyal hizmet mesleğidir. Sosyal hizmet uzmanları yoksulluğa dayalı ihtiyaç ve sorunların saptanarak koruyucu önleyici hizmetlerin planlamasında ve sosyal politikaların oluşturulmasında aktif rol alırlar. Bu makalede yaşlı yoksulluğu için risk etmeni olarak görülen yaşlılığa ilişkin fizyolojik değişimler, toplumsal cinsiyet, istihdam, sosyal yardımlar, ayrımcılık, sosyal izolasyon ve yalnızlık konuları sosyal hizmet mesleki bakış açısıyla ele alınarak yoksulluğun önlemesine ilişkin öneriler sunulacaktır.
Anahtar Kelimeler

\begin{tabular}{r} 
Yaşlılık \\
Yoksulluk \\
Yaşlı Yoksulluğu \\
Sosyal Hizmet \\
Makale Hakkında \\
\hline Geliş Tarihi: 02.03.2021 \\
Kabul Tarihi: 24.09 .2021
\end{tabular}

Doi: $10.18026 /$ cbayarsos.889976

\section{Investigation of Poverty of Elderly as a Social Problem Area}

\begin{abstract}
Poverty has been a problem affecting all societies from past to present. The poverty that can be experienced in various social groups affects especially disadvantaged groups such as the elderly, disabled, women and children, who are at the focal point of social work more deeply. Older people constitute an important risk group affected by poverty and experience various aspects of poverty. Social work is one of the leading academic disciplines in combating poverty. Social workers take an active role in determining the needs and problems based on poverty, planning preventive and preventive services and establishing social policies. In this article, physiological changes regarding old age, which are seen as risk factors for elderly poverty, gender, employment, social assistance, discrimination, social isolation and loneliness will be discussed from a social work professional perspective and suggestions for poverty prevention will be presented.
\end{abstract}

Keywords

Old age

Poverty

Elderly Poverty

Social Work

\section{About Article}

Received: 02.03.2021

Accepted: 24.09 .2021

Doi: $10.18026 /$ cbayarsos. 889976

a İletişim Yazarı: gizembykl5@gmail.com

b Doktora Öğrencisi, Manisa CBÜ Sağlık Bilimleri Enstitüsü Sosyal Hizmet Anabilim Dalı, ORCID. 0000-0003-0978-7439 


\section{Giriş}

Geçmişten günümüze hiçbir zaman etkisi bugün ki kadar hissedilmemiş bir gelir dağılımı eşitsizliğini derinleştiren küresel kapitalizm toplumların önüne yoksullaşan insan sorununu koymuştur. Teknoloji, küresel bağlar ve zenginlik artmasına rağmen yoksulluk da artmaktadır. Küresel zenginliğin içinde derinleşen bir yoksulluk söz konusudur. Gelir adaletsizliği ülkeler arasında olduğu gibi bir ülke içindeki insanlar arasında da yaşanmaktadır. Bu eşitsiz gelir dağılımı toplumda çeşitli gruplar tarafından deneyimlenmekte birlikte yaşlılar zararı en fazla hisseden kesimlerin başında gelmektedir. Az gelişmiş ülkelerin yanında gelişmekte olan ve gelişmiş ülkelerde de düşük gelir ve tüketime sahip olan, yeterli beslenemeyen, sağlık sisteminden, eğitim hizmetlerinden yararlanamayan fakat seslerini duyuramayan milyonlarca yoksul insan yaşamaktadır (Kalınkara, Argun, \& Güler, 2014). Küreselleşmeyle derinleşen yoksulluk olgusu günümüzde konuşulması gerekli olan sorun alanlarındandır (Karadeniz \& Öztepe, 2013). Türkiye de yoksulluk üzerinde sürekli konuşulan konulardan olmasına rağmen ekonomik değişimlerden yakından etkilenen yaşlı nüfus üzerinde az durulmaktadır (Muammer \& Közleme, 2017). Yaşlı nüfus yoksulluktan etkilenen risk gruplarının başında gelmektedir. Yoksulluk yaşlılık döneminin bireysel ve toplumsal sorunlarıyla yakından ilintilidir. Çoğu zaman kişisel sorumluluk olarak algılanan yoksulluk temelde gelir adaletsizlikleri, sosyal politika ve sosyal güvenlik sistemlerindeki eşitsizliklerden kaynaklanmaktadır. Sosyal hizmet mesleği insan hakları ve sosyal adalet ilkelerini benimseyerek sosyal sorunlara birey, grup, aile ve toplumsal düzeyde müdahale ederek bireylerin yaşam standartlarının arttırılması amacıyla hizmet vermektedir. Yoksulluk sosyal hizmet mesleği için bireysel ve toplumsal refahı etkileyen sosyal sorunların en önemlilerinden biridir. Yaşlı nüfusun yoksulluğu yaşlının yaşam kalitesini düşüren, sağlığını tehdit eden, başarılı yaşlanma deneyimlerini olumsuz etkileyen bir olgu olarak görülmektedir. Bu nedenle de yaşlılık ve sosyal hizmet alanında gerçekleştirilen sosyal hizmet uygulamaları yoksulluğa yönelik koruyucu, önleyici ve destekleyici hizmetleri içermektedir. Bu makalenin amacı yoksulluğu yaşlılık boyutu ile alarak yaşlı yoksulluğu için risk etmeni olarak görülen yaşlılık deneyimleri sosyal hizmet bakış açısıyla incelenerek yoksulluğu azaltmaya ve önlemeye ilişkin önerilerin sunulmasıdır.

\section{Yaşlılık ve Yaşlanma}

Yaşlılık kelime anlamı ile artan yaşın etkilerinin ortaya çıkmasıyla birlikte yaşlı olma hali olarak tanımlanmaktadır. Yaşlanma ise yaşın artması anlamına gelmektedir ve kronolojik olarak 65 yaş ve üzeri olarak kabul edilmektedir. Dünya Sağlık Örgütü yaşlılığı üç kategoriye ayırmıştır. 65-74 yaş arası genç yaşlı, 75-84 yaş arası orta yaşlı, 85 yaş ve üzeri ise ileri yaşlılık olarak tanımlanmaktadır (Beğer \& Yavuzer, 2012).

Doğum ve ölüm oranlarındaki azalmalar, sağlık, bilim teknolojide yaşanan gelişmeler ülkemizde ve dünyada demografik bir dönüşüm yaşanmasına neden olmuştur. Yaş yapısının değişmesiyle çocuk ve gençlerin sayısının azalmasına karşılık yaşlı sayısının artması olarak tanımlanan nüfus yaşlanması yaşlılı̆̆ gereken bir olgu haline getirmiştir (Mandıracıoğlu, 2010). Ortalama yaşam süresinin uzaması istenen bir durumdur. Fakat artan yaşla birlikte ortaya çıkan gereksinimler yaşlıları dezavantajlı bireyler haline getirebilmekte ve yaşlılığa ilişkin sorunlar toplumsal bir sorun haline gelebilmektedir. Ülkemizde 65 yaş üstü kişi sayısı 2019 yılı itibariyle 7 milyon 550 bin 727 kişidir olmuştur ve yaşlı nüfusun toplam nüfus içerisindeki oranı $\% 9,1^{\prime}$ dir. $\% 44,2^{\prime}$ sini 
erkeklerin; \%55,8'ini kadınların oluşturduğu yaşlı nüfus için doğuştan beklenen yaşam süresi ise \% 78,3 yıldır (TÜIK, 2020). Ülkemiz diğer ülkelerle kıyaslandığında genç ve dinamik bir nüfus yapısını sahiptir. Ancak 2030 yılı ve sonrasında yaşlanmanın etkileri artan yaşam süreleri ve azalan doğum oranlarıyla yoğun bir şekilde hissedilmeye başlanacaktır (Yumurtacl, 2013).

Yaşlılık fizyolojik, biyolojik, psikolojik, sosyal kültürel ve ekonomik yönleri ile bir bütündür. Yaşlanma bir hastalık olmamakla birlikte azalan fiziksel güç, duyu organlarına bağlı gerilemeler, sistemler ile ilgili artan sağlık sorunları yaşlanmanın fizyolojik ve biyolojik boyutu ile ilişkilidir (Yerli, 2017). Yaşlı kişilerin alg1, dikkat, düşünme anlama, öğrenme gibi zihinsel ve ruhsal özelliklerinde yaşanan değişmeler ise yaşlanmanın psikolojik boyutunu ifade eder (Karatas \& Durmaz, 2017). Bireyin toplumsal konumu, rol, statü, sosyal destek ağları yaşlanmanın sosyal boyut ile ilişkiliyken emeklilik ile birlikte ortaya çıkan gelir ve sosyal güvenlik ile ilgili durumlar ekonomik boyutu içermektedir (Yerli, 2017). Yaşlılık dönemini anlayabilmek için yaşlanmanın çok boyutlu özelliklerini bilmek önemlidir. Çünkü bu dönemde yaşanan sorunlar ve ihtiyaçlar yaşlılığın tüm yönleriyle ilişkili olarak ortaya çıkmaktadır. Yaşlı nüfusun en yaygın toplumsal sorunları uygunsuz konut koşulları, aile desteğindeki azalmalar, yaşlanmanın fizyolojik belirtileri ve artan sağlık sorunları, ayrımcılık, damgalanma, sosyal güvenlik ile ilişkili sorunlar, yoksulluk ve düşük gelir şeklinde sıralanabilir (Kurt, Beyaztaş, \& Erkol, 2010).

\section{Yaşlı Yoksulluğu}

1980'lerden itibaren yaşanan sosyal, kültürel, ekonomik değişiklikler yoksulluğun kavram olarak tartışılmasını hızlandırmıştır. Sadece ekonomik olarak gelişmemiş ülkelerde değil, gelişmiş ve gelişmekte olan ülkelerinde ortak sorunu olan yoksulluk, devletlerin her dönem gündeminde olmuştur. Dünya Kalkınma Raporunda Dünya Bankası tarafından ana tema olarak yoksulluğun ele alınması bu alanda yapılan çalışmalara da hız kazandırmıştır (Taş \& Özcan, 2012). Yoksulluğun tanımlanması, üzerinde ortak kavramlar ve noktalar olsa da çeşitli görüşlerin olması nedeniyle oldukça güçtür. Yoksul olmak ve zengin olmak kişiden kişiye ve toplumdan topluma değişen öznel kavramlardır. Bu nedenle ortak bir yoksulluk tanımına ulaşmak zordur. Yoksulluğu tanımlarken kimin yoksul sayılacağının belirlenmesi önemlidir. Bunun için çeşitli yoksulluk türlerine bakmak gerekir. Mutlak yoksulluk, bireyin veya hane halkının yaşamını minimum düzeyde sürdürebilmesi ve en temel gereksinimlerini karşılayabilmesi için ihtiyacı olan gelir düzeyine sahip olmamasıdır (Ensari, 2010). Yeterli gıdayı temin edemeyen, karnını doyuramayan, temiz suya ulaşamayan, sağlık sistemine erişemeyen, evi olmayan, temel eğitim göremeyen insanlar mutlak yoksulluk tanımlamasının içindedir. Bu mutlak sınır beraberinde göreli bir yoksulluk tanımını da getirmiştir (Kalınkara et al., 2014). Mutlak yoksulluk gıda ve gıda dışında yapılan gereksinimler için gerekli tüketim harcamalarıyla ilişkiliyken (Karadeniz \& Öztepe, 2013), göreli yoksulluk ise bireylerin toplumda belli bir refah seviyesinin altında olması durumudur (Ensari, 2010). İnsanın toplumsal bir varlık olmasından hareket ederek hem biyolojik ihtiyaçlara hem de toplumsal gereksinimlere vurgu yapar. İhtiyaç duyulan minimum temel gereksinimlerin yanında kültürel ve toplumsal ihtiyaçlarında göz önünde bulundurulması gerektiğine dayanır. Göreli yoksulluk, bireylerin diğer insanlara kıyasla sahip oldukları gelir dağılımındaki eşitsizliğe ilişkin refahı ile ilişkilidir (Karadeniz \& Öztepe, 2013). Ünlü iktisatçı Amartya Sen yoksulluğu belirli bir asgari kabiliyeti devam ettirememek olarak tanımlamaktadır (Uzun, 2001). 
Yoksulluk Sen'e göre isteklerimizi gerçekleştirebilme düzeyimize göre belirlenmektedir. Gelir tek başına yeterli değildir iyi bir hayat sürdürebilmek için gerekli olan faktörlerden sadece biridir (Kalınkara et al., 2014). Yalnızca alınıp satılan şeylere yani gelire odaklanmak yoksulluğu değerlendirmede yetersiz kalır. Bireylerin yaşamlarındaki çeşitli işlevlerini sürdürebilme, toplumsal yaşama katılma, toplumda var olabilme kapasitelerini geliştirebilme imkanlarına da sahip olması gerekir (Metin, 2014).

İlerleyen yıllarda ülkelerin nüfus yapılarında hızlı değişimler yaşanacağı öngörülmektedir. Yaş yapılarında en belirgin değişiklik yaşlı nüfus içerisinde gerçekleşecektir. Ülkemizde yaşayan yaşlıların çoğunluğunu eğitim seviyesi düşük, ekonomik olanaklı kısıtlı ve tek başına yaşayan bireyler oluşturmaktadır. Artan yaşlı nüfusun ihtiyaçlarının karşılanması gelecek yıllarda önemli bir sosyal sorun olarak gündemimizde olacaktır. Yaşlılar yoksulluktan etkilenen önemli bir risk grubunu oluşturmaktadır. Yaşlanma ile birlikte yaşanan fizyolojik değişimlerin yanında emeklilik sonucu azalan gelir, isteğe bağlı veya zorunlu nedenlerle çalışma hayatından uzaklaşma ya da düşük ücretlerle güvencesiz çalışma, ayrımcılık ve sosyal konumun zayıflaması gibi çok yönlü etmenlerin bir araya gelmesiyle yaşlı yoksulluğu ortaya çıkmaktadır. Yoksulluğun yaşlılık deneyimlerine etkisi çok boyutludur. İnsanlar yaşlandıkça iş yaşamından ayrılarak üretimden ve kazanç elde etmekten uzaklaşırlar. Bu süreçte barınma, ulaşım, sağlık, sosyal ilişkiler gibi faaliyetlerin sürdürülmesinde problemler ortaya çıkabilmektedir (Karadeniz \& Öztepe, 2013). Yaşlılık döneminde emeklilikle birlikte gelirin azalması, sosyal rollerin değişmesi, bilişsel kayıplar, sosyal statünün zayıflaması, sosyal desteğin azalması, sağlık sorunları, üretimden çekilme gibi sorunların birbiri ile kesişmesiyle yaşlılar yoksulluğun çeşitli görünümlerini deneyimlemektedir. Yoksulluk açlık, yetersiz beslenme, sağlık hizmetlerinden yararlanamama, hastalık, vefat, güvensiz çevre ve barınma, ayrımcılık, sosyal izolasyon, yalnızlık biçimlerinde yaşlıları yaşamlarında kendini göstermektedir (Kalkınma Bakanlığı, 2013). Gelir ve yaşam koşulları araştırma sonuçlarına göre, 2018 yılında Türkiye geneli yoksulluk oranı \%21,2 yaşlı nüfusun yoksulluk oranı ise \%16,4 olarak bulunmuştur (TÜİK, 2020). Beş yılda bir yayınlanan Türkiye Aile Yapısı Araştırması (TAYA) 2016 sonuçlarına göre ise ülkemizde yaşayan yaşlıların \%81,6'sı son bir hafta içinde ayni nakdi gelir getiren bir işte çalışmadıklarını belirtmişlerdir (Aile, 2019).

\section{Sosyal Bir Sorun Alanı Olarak Yaşlı Yoksulluğunun İncelenmesi}

Sosyal adalet ve insan hakları çerçevesince toplumsal gelişmeyi, değişmeyi amaçlayan sosyal hizmet mesleğinin hedefinde pek çok grup bulunmaktadır. Bu hedef gruplardan en önemlilerinden biri de yaşlılardır. Sosyal hizmet uzmanları yaş almış bireylerin fiziksel, sosyal, ruhsal, çevresel, manevi, ekonomik beklenti ve ihtiyaçlarının karşılanması için birey, grup, aile ve toplum temelli uygulamaları geliştirmek ve gerçekleştirmek için mesleki çalışmalarını sürdürürler (Tekindal, 2019). Sosyal hizmetlerin sunumu her ülkenin kendine özgü toplumsal yapısından etkilense de genel olarak kamu kurum ve kuruluşları, özel sektör ve kar amacı gütmeyen sivil toplum aracılı̆̆ılyla gerçekleştirilmektedir. Ülkemizde yaşlılara yönelik sosyal hizmetlerde ana sorumluluk Aile, Çalışma ve Sosyal Hizmetler Bakanlığındadır. Bakanlık bünyesinde Huzurevleri, Yaşlı Bakım ve Rehabilitasyon Merkezleri, Yaşlı Yaşam Evleri, yaşlılarında barınabildiği Engelli Bakım Kuruluşları, Engelsiz Yaşam Merkezleri, Aile Danışma ve Rehabilitasyon Merkezleri, Evde Bakıma Destek Hizmetleri, Özel Bakım Merkezleri, Gündüzlü Bakım Hizmetleri gibi uygulamalar ile yaşlılara yönelik hizmet sunumları geniş bir yelpazede yapılmaktadır (Karakuş, 2019). 
Yoksulluk geçmişten günümüze tüm toplumları etkileyen bir sorun olmuştur. Dünya ekonomilerinin gelişmesi ve teknolojinin ilerlemesine rağmen yoksulluğun azalmıyor olması toplumsal kaynakların dağıtımındaki eşitsizlik ve bazı insanların kaynaklara hiç erişememe veya sınırlı erişimi ile yakından ilişkilidir. Çeşitli toplumsal gruplarda yaşanabilen yoksulluk özellikle sosyal hizmetin odak noktasında olan yaşlı, engelli, kadın, çocuk gibi dezavantajlı grupları daha derinden etkilemektedir (Muammer \& Közleme, 2017). Yoksullukla mücadele de önde gelen akademik disiplinlerden biri de sosyal hizmet mesleğidir. Yoksulluk mesleğin doğuşunda da önemli bir yere sahiptir. 16. yüzyılda ekonomik nedenlere bağlı olarak savunuculuğu, eşitliği, adaleti gerçekleştirme çabaları sosyal hizmet mesleğinin gelişmesine katkı vermiştir. Yoksulluğun küresel çapta bir sorun olması ekonomik nedenlerinin yanında bireylerin sosyal yaşamdaki haklarını kullanmaktan da yoksun hele gelebilmeleri riskiyle karşı karşıya olmalarıyla yakından ilişkilidir. Yoksul olmak ekonomik gelirden yoksun olmanın yanında sosyal çevreden izole olma, kendi hayatı üzerinde kontrolünün azalması, ayrımcllı̆̆a maruz kalma, kişisel potansiyelini kullanamama, sosyal olanaklara ulaşamama gibi temel hakların kullanılmasına da engel teşkil etmektedir (İçağasığlu Çoban, 2014). Bu bağlamda yoksullukla mücadele geniş bir perspektifte gerçekleştirilecek mesleki uygulamaların organize edilmesi ile mümkün olabilir. Sosyal hizmet uzmanları bu mücadele içinde hem bireylere ihtiyaç duydukları kaynaklarla ilişkili birebir hizmet sunmak hem de yoksulluğun ortadan kaldırılması için politika geliştirmede süreçlerine aktif olarak katılmak sorumluluğunu üstlenmektedir.

Yaşlı alanında çalışan sosyal hizmet uzmanları yaşlıların fiziksel, psikolojik ve sosyal iyilik hallerinin arttırılarak yaşam kalitesinin en üst düzeyde sürdürülebilmesi için mesleki çalışmalarını yürütürler. Bireyleri çeşitli yönlerden etkileyen sorunlara yönelerek çözüm üretmeye yardımcı olan sosyal hizmet mesleğinin önemli mücadele alanlarından biri de yaşlı yoksulluğudur. Sosyal hizmet uzmanları yoksulluğa dayalı ihtiyaç ve sorunların saptanarak koruyucu önleyici hizmetlerin planlamasında ve sosyal politikaların oluşturulmasında aktif rol alırlar. Yaşlı yoksulluğuna neden olabilecek bakım, barınma, beslenme, sağlığa erişim, sosyal güvenlikten yararlanma gibi bireysel düzeydeki temel ihtiyaçların karşılanmasında kaynak sağlayıcı, bağlantı kurucu ve danışman olarak hareket ederler. Bunun yanında yaş ayrımcılığı, damgalanma, yalnızlık, sosyal izolasyon gibi toplumsal düzeydeki sorunlara yönelik ihtiyaçların yoksulluğu tetikleyici etkisinin engellenmesi için birey, grup, aile ve toplum bazında değişim ajanı ve savunuculuk rolleri ile mesleki faaliyetlerini sürdürürler. Sosyal hizmet mesleği yaşlı yoksulluğu ile mücadele ederken yoksulluğa zemin hazırlayan bireysel ve toplumsal etmenlerin olumsuz etkilerinin ortadan kaldırılması veya en aza indirgenmesi için sorunların tanımlanmasında, gerekli müdahalelerin planlanmasında ve hizmetlerin uygulanmasında görev alırlar. Bu çalışmada yaşlı yoksulluğu için risk etmeni olarak görülen yaşlılığa ilişkin fizyolojik değişimler, toplumsal cinsiyet, istihdam, sosyal yardımlar, ayrımcılık, sosyal izolasyon ve yalnızlık konuları sosyal hizmet mesleki bakış açısıyla ele alınarak yoksulluğun önlemesine ilişkin öneriler sunulacaktır.

\section{Yaşlılı̆̆a İlişkin Fizyolojik Değişimler}

Doğal süreçlerle birlikte insan organizmasının işlevselliğinde meydana gelen azalmayı ifade eden biyolojik yaşlanma hastalık olmaksızın anatomik ve fizyolojik değişimleri içerir. Döllenme ile başlayan yaşlanma birey yaş aldıkça hızını artırır. Orta yaş sonuna doğru kas 
gücünün zayıflaması, yavaş hareket etme, görme, işitme gibi duyuların zayıflaması, kronik hastalık sıklığının artması belirtileri görülmeye başlar (Kalınkara et al., 2014). Yaşlanmayla birlikte ortaya çıkan fizyolojik değişimler yoksulluk riski ile yakından ilişkilidir. Artan sağlık sorunlarının getirdiği ek maliyetler yaşlıların yoksullaşmasında önemli bir etkiye sahiptir. Yaşlanan bireyler diğer nüfus gruplarına göre sağlik hizmetlerine daha fazla gereksinim duyar. Ancak yaşlılara yönelik sağlık hizmetleri değerlendirildiğinde gelir yoksunluğu nedeniyle adil olmayan sağlık politikaları ve uygulamaları olduğu görülmektedir (Nazlıer Keser, 2019). Fiziksel yaşlanma ile çalışamayacak durumda olan yaşlılar hastalıkları nedeniyle sağlık sisteminden yararlanmaları gerektiğinde sosyal güvenceden yoksun iseler sağlığa erişimde ciddi sıkıntı yaşarlar (Danış, 2009). Sosyal güvence sisteminden faydalanamayan yaşlılar sağlık sorunlarının yanında bir de ekonomik sıkıntılarla baş etmek durumunda kalır ve yoksulluk döngüsünün bir parçası haline gelir. Yaşlılığın getirdiği fizyolojik değişimler bireylerin çalışma kapasitelerini etkilemektedir. Yaş ilerledikçe bireylerin dayanıklılığında ve iş temposuna uyum sağlamada azalmalar olmaktadır (Ofluoğlu \& Özbucak Albar, 2017). Kas ve iskelet sisteminde zayıflama, hareket yeteneğinin azalması, kullanılan ilaçların yaşam kalitesine etkisi, algılama, öğrenme, tepki verme ve çözüm üretme gibi becerilerin azalması gibi sorunlar yaşlıyı çalışma yaşamından uzaklaştırabilir. Çalışmaya devam etmek isteyen yaşlılar ise oldukça az seçenek içerisinden düşük statü ve ücrette çalışmak durumunda kalabilmektedir (Özen \& Özbek, 2017). Çalışma yaşamında hem yaşlılara hem de gençlere ihtiyaç olmasına rağmen yaşlıların bağımlı olduklarına, dinamikliklerini ve üretkenliklerini kaybettiklerine yönelik algılar yaşlılar sağlıklı olup çalışabilecek durumda olsalar bile onları toplumsal hayattan uzaklaştırarak yoksulluk riski ile karşı karşıya bırakmaktadır.

Yaşanan fizyolojik değişimler hayatın doğal akışının bir parçasıdır. Yoksullaşma riskine neden olabilecek artan sağlık sorunlarının çözümlenmesi için koruyucu ve önleyici sağlık hizmetlerinin sunumunun adaletli ve hakkaniyetli olarak temel yaşam hakkı çerçevesi içerisinde yaşlılara ulaştırılması gerekmektedir. Sosyal güvenlik sisteminden tüm yaşlıların koşulsuz aktif bir şekilde yararlanmalarına imkan tanıyan sosyal güvenlik politikalarının planlanması yaşın getirdiği biyolojik değişimlerin yoksulluk çukuruna düşülmesini önleyici en önemli adımlardan biri olduğu söylenebilir. Yaşlanan birey çalışma yaşamına devam etmek istiyorsa iş sağ lığı ve güvenliğine uygun sağlıklı iş ortamları oluşturarak yaşlının çalışma gücü ve kapasitesine uygun düzenlemeler yapılmalıdır. İş gücünde yaşlının deneyim ve tecrübelerinden yararlanılmalı ve gelişen teknolojiyle değişen çalışma hayatına uyum sağlamaları için gerekli mesleki çalışmalar yürütülmelidir. Yaşlı bireylerin yalnızca yaşlarından ötürü sağlıksız oldukları bu nedenle iş yaşamında başarılı olamayacakları algısıyla mücadele edebilmek adına yaş ayrımcılığına yönelik yasal düzenlemelerin yanında makro boyutlu toplum çalışmalarının yapılması yaşlının fiziksel kapasitesine ve sağlığına elverişli alanlarda hayatın içinde aktif yer almalarına katkı sağlayacaktır.

\section{Toplumsal Cinsiyet}

Yaşlı bireylerin yaşadıkları problemlerin nicelikleri ve nitelikleri içinde yaşadıkları toplum kadar toplumsal cinsiyet rolleri ile de yakından ilişkilidir. Yaşlı yoksulluğu toplumsal cinsiyet temelinde ele alındığında kadınların yaşadığı yoksulluk ön plana çıkmaktadır. Yaşlı kadınların sayısı giderek arttığından önümüzdeki yıllarda yaşlılığın genel görüntüsüne yön verecek olan kadınların yaşadıkları problemlerin toplumsal cinsiyet temelli olduğu açıkça 
görülmektedir. Pek çoğu gençlik dönemlerinde eğitim fırsatlarına erişememiş, herhangi bir meslek edinememiş, bireysel potansiyellerini kullanma fırsatına sahip olamamıştır. $\mathrm{Bu}$ nedenle yaşlılıklarında ekonomik güvenceden yoksun, eşine, çocuklarına ve akrabalarına bağımlı, sosyal yardımlara muhtaç bir yaşlılık deneyimlemektedirler (Kalınkara, 2016). Kadınlarda beklenen yaşam süresinin erkeklerden daha uzun olması, ileri yaşta kronik hastalıkların görülme sıklığı ve engelliliğin kadınlarda daha yüksek olmasından yaşlı kadınlar yoksulluğu daha derinden yaşamaktadır. Kadınların gençlikte çocuk bakımı gibi sebeplerle çalışma süresinin erkeklerden daha az olması nedeniyle emeklilik dönemlerinde kadın erkek arasındaki gelir farklılıkları yoksullukta belirleyici olmaktadır. Aynı zamanda erkeklerdeki beklenen yaşam süresi kadınlardan daha kısa olduğundan yaşlı erkeğin bakımının eşi tarafından yapılarak ücretsiz bir şekilde bakım ihtiyacının da karşılanıyor olması da erkeklerin yaşam kalitelerini arttırmaktadır. Eşin vefatı ile geride kalan kadın düzenli gelirden ve sosyal güvenceden mahrum durumda kalabilmektedir. Gençlik ve yetişkinlik dönemlerinde kadınların düşük ücretli işlerde çalışmış olmaları, ev işleri, çocuk bakımı, anne baba bakımı gibi emekleriyle ücret elde etmemeleri, mal mülk sahibi olmalarının kısıtlılığı gibi nedenlerle yaşlı kadınlar çoğunlukla yoksulluk içinde hayatlarını sürdürürler (Buz, 2015). Yaşlı nüfusta yoksulluk oranı cinsiyet temelli incelendiğinde yoksul yaşlı erkek oranı \%14,4 iken yoksul kadın yaşlı oranı \%17,9 olarak görülmektedir (TÜİK, 2020). Cinsiyete dayalı istihdam durumlarına bakıldığında ise yaşlı kadınların \%91,1 i yaşlı erkeklerin ise \%70,7 si ayni nakdi gelir getiren bir işte çalışmadıklarını belirtmişledir (Aile, 2019).

Yapılan birçok çalışmada yaşlı kadınların ekonomik yönden daha incinebilir oldukları saptanmıştır. Çalışma hayatında kadınların gençlik yıllarından itibaren düzenli gelir elde edebilecekleri güvenli iş ortamlarının sağlanması, cinsiyet temelli adaleti ve eşitliği sağlayacak politikaların geliştirilmesi son derece önemlidir. Yaşlı kadınların yoksulluğunu ise ileri yaşlarda eğitim olanakları sağlamak ve istihdamı arttırmak ile azaltmaya çalışmak uygun olmayabilir. Çalışma imkanı olan yaşlı kadınların çalışmaya teşvik edilmesi son derece önemlidir fakat bu her zaman mümkün olmayabilir. Bu dönemde özellikle tek başına yaşayan kadın yaşlıların varsa barınma sorunlarına çözmek, huzurevleri bakım ve rehabilitasyon merkezlerinden faydalanmalarını sağlamak, ihtiyaç dahilinde evde bakım hizmetlerinden yararlandırmak gereklidir. Sosyal yardımların yaşı kadınların ihtiyacını karşılayacak seviyeye çıkarılması ve muhtaç tüm kadınlar için yaygınlaştırılması, sağlık harcamalarının karşılanması ve sosyal destek ağlarının düzenlenmesi yoksullaşma riskiyle mücadele etmek için sağlanacak sosyal hizmet uygulamaları olarak sayılabilir.

\section{Yaşlılıkta İstihdam}

Yaşlılık döneminde karşılaşılan en önemli sorunlardan biri çalışılan döneme göre gelirin azalması neticesinde yaşanan yoksulluktur. Emekli aylıklarının düşük olması, iş gücüne katılmada yaşanan sorunlar, kayıt dışı çalışmanın fazla olması, sosyal güvenlik ile ilişkili sorunlar ve en temelde gelir adaletsizliği yoksullaşmayı arttırmaktadır (Karadeniz \& Öztepe, 2013). 19. yüzyılın sonlarında insanların çalışma yaşamından ayrılması belirli bir yaş kriterine bağlı değildi. Bireyler sağlıkları el verdiği sürece çalışmaya devam etmekteydiler. Günümüzde ise çalışma hayatından çekilmek emekli olmak adı altında bir yaş kriterine bağlanmıştır ve hemen her ülkede farklılıklar olmasına rağmen ortalama 60-65 yaş sınırı getirilmiştir. Çalışma yaşamının sonu olarak nitelendirilen emeklilik bireyleri yaşlılık olgusuyla karşı karşıya bırakan en önemli deneyim olmaktadır. Kişide ekonomik kayıpların 
yaşanmasının yanında yalnızlık, işe yaramamazlık, kimlik ve ait olma duygusunda eksilme, sosyal ortamını yitirme gibi sorunları da beraberinde getirebilen emeklilik çok da kolay uyum sağlanabilen bir süreç değildir (Şentürk, 2018). Yaşlılık ekonomik tanımlamalarıyla emekli olunan dönemde başlamaktadır. Bu süreçte bireylerin talep ve gereksinimlerini karşılayabilmesinde ve yaşam doyumunun yüksek olmasında ekonomik fonksiyonlarının rolü son derece önemlidir (Stoller \& Stoller, 2003). Emeklilik kimi zaman yetişkinlerin üzerine hayaller ve planlar kurduğu bir dönem olmanın yanında emekli aylıklarının yetersiz olması yoksullaşmanın da ana sebebi olabilmektedir. Türkiye'de yaşlı yoksulluğu ile ilişkili önemli etmenlerden biride kişilerin iş hayatı boyunca belirli bir süre ya da tamamen kayıt dışı istihdam edilmesidir. Sigortasız çalışan bireyler yaşlılıkta hak sahibi olamamaktadır (Karadeniz \& Öztepe, 2013). Emekli olma yaşı gelen bireyler çalışma yaşamının içinde olmak isteseler bile çeşitli engellerle karşılaşabilmektedir. Günümüzde iş yaşamında yaşlılara yer bulmak oldukça zordur. Hemen hemen tüm sektörler yaşlılar yerine gençleri çalıştırmayı tercih etmektedir. Gençlerin daha aktif, daha dinamik ve daha üretken oldukları inancının hakim olması yaşlının kendine uygun iş imkanı bulmasını oldukça sınırlamaktadır. Yaşlının çalışması için kabul gören işler fiziksel yapısına uygun olmayan genellikle düşük ücretli yaşlının iyilik halini tehdit eden nitelikte olmaktadır.

Yaşlılara çalışma hayatında kalma ve emekliliğe ayrılma konusunda seçim yapabilecek fırsatları sağlamak oldukça önemlidir. Çalışmaya devam etmek isteyen yaşlıların istihdamı için iş yerlerinin teşviki ve yaşlıya becerilerine uygun, esnek, güvenli çalışma ortamları sağlanmalı ve böylece aktif yaşlanma politikalarına destek verilmelidir. Kayıtlı istihdam için hem çalışanlara hem de işverenlere hak ve sorumluluklarının farkındalığının kazandırılması gereklidir. Bireylerin emekli olduklarında yoksunlukla baş etmek durumda kalmayacak asgari bir gelire sahip olmaları için sosyal sigorta ve güvenlik sistemleri iyileştirilmelidir. Emekliliği çeşitli nedenlerle hak edememiş olan yaşlıların sağlık hizmetleri başta olmak üzere sosyal güvenceden yararlanmaları ve yaşamlarını idame ettirecek düzeydeki yaşlılık aylıklarından faydalandırılmalarına olanak sağlayacak sosyal güvenlik politikaları desteklenmelidir. Yaşlılık döneminde istihdamın sürdürülmesi yaşlıya aktif yaşlanma imkanı sunarak sağlığın korunması, sosyalleşme, gelir elde etme imkanları ile yaşlı yaşam kalitesinin korunmasına da katkı verecektir. Sosyal hizmet mesleği yaşlılara yönelik müdahale geliştirirken çok boyutlu perspektifte yaşlının hayatına dokunur. Yaşlının talebi doğrultusunda istihdamın uygun koşullarda sürdürülmesi yoksulluğu azaltmanın yanında hayatın diğer alanlarının da bireyi güçlendirici ve destekleyici imkan sağlayabilir.

\section{Yaşlilara Yönelik Sosyal Yardımlar}

Yaşlılarda ekonomik ihtiyaçların baş edilmesi zor sonuçlar doğurduğu ve bireylerin maddi manevi bağımsızlıklarını tehdit ettiği bilinmektedir. Sosyal devletin bir gereği olarak yoksulluk riskine karşı gerekli önlemleri almak yaşlılar için temel hak olarak görülmektedir (İştar, 2018). Yoksullukla karşı karşıya kalmış kesimin gereksinimlerini karşılamak ve gelir dağılımında adalete katkı sunmak için devlet tarafından sunulan ayni nakdi hizmetler sosyal yardımların kapsamındadır (Zengin, Şahin, \& Özcan, 2012). Günümüzde sosyal yardımların sunulmasında esas yetki Aile, Çalışma ve Sosyal Hizmetler Bakanlığı Sosyal Yardımlar Genel Müdürlüğü bünyesinde yürütülmektedir. Engelli Evde Bakım Sosyal Yardım Aylığı, Eşi Vefat Eden Yaşlı Kadınlara Yönelik Yardımlar, Sosyal Ekonomik Destek Yönetmeliği Kapsamında Yapılan Sosyal ve Ekonomik Yardımlar, Sosyal Yardımlaşma ve Dayanışma Vakıfları 
Tarafından Yaşlılara Yapılan Yardımlar gibi başlıklar altında uygun şartları sağlayan yaşlıların yardımlardan faydalanması sağlanmaktadır (Karakuş, 2019). Bakanlık tarafından sosyal yardımların daha etkili ve hızlı organize edilebilmesi için Sosyal Yardım Bilgi Sistemi (SOYBİS), Bütünleşik Sosyal Yardım Hizmetleri (BSYH) ve ALO 144 Sosyal Yardım Hattı projelerini yürütmektedir (İştar, 2018). 2021 yılı itibariyle 65 yaş üstü yaşlı aylığg 763,67 TL olarak belirlenmiştir. Bu yardımdan faydalanmak için kişinin sosyal güvencesinin olmaması kendisi ve eşi dikkate alınmak suretiyle kişi başına düşen aylık geliri net asgari ücretin 1/3'ünden (2021 yılı için 852,53 TL) az olması gerekmektedir (Aile, 2021).

Sunulan sosyal yardımların temel amacı kişilere ekonomik destekte bulunmaktır. Yaşlılar açısından değerlendiğinde ekonomik yardımların elbette ki katkısı vardır ancak yoksulluğu önleyici ve ortadan kaldırıcı etkisinin yeterliliği tartışılmaktadır. Ülkemizde sosyal yardımlardan faydalanmaya hak kazanmak için bireyin sağlaması gereken koşullar oldukça zordur. Bu nedenle sosyal yardımlara yönelik aksaklıkların çözümlenmesi ve yardımların miktarının kişinin hayatını idame ettirecek seviyeye gelmesi gerekmektedir. Günümüzde verilen sosyal yardım miktarları yaşlılarda yoksulluğu ortadan kaldırmaya yeterli değildir. Sosyal yardımların yoksulluğu önleme de ana hizmet modeli haline getirilmeden destekleyici hizmetler olarak planlanması ve bireylerin düzenli gelir elde etmesini sağlayacak sistemlerin kurulması teşvik edilmelidir. Sosyal hizmetlerin sunumunda bir aracı olarak sosyal yardımlar uygulamalar için önemli bir yere sahiptir. Sosyal hizmet uzmanları sosyal yardıma ihtiyaç duyan kişilerin doğru tespit edilmesinde ve ayni nakdi hizmetlerin dağıtımında aktif rol alırlar. Bireylerin başkalarına bağımlı olmadan kendi yaşamlarını idame ettirebilmelerine destek sağlamak için sunulan sosyal yardımlarda yaşanan tıkanıklıkları ve eksiklikleri analiz ederek değiştirici ve geliştirici yönde çalışmalar yapmak mesleki bir sorunluluktur. Bireysel bağımsızlığı esas alan sosyal hizmet mesleği için sosyal yardım sunmadaki esas amaç, kişinin yardıma muhtaç olmadan en kısa sürede düzenli bir gelir elde etme olanağına ulaşmasına imkan sağlayacak sosyal politikaların gelişimine katkı sunmak olmalıdır.

\section{Ayrumcilik}

Yaş ayrımcılığı bir kişiye yalnızca yaşı ilerlediği için toplumsal, siyasal, kültürel ve ekonomik alanlarda farklı tutum, davranış, hareket ve kurumsal düzenlemeler gösterilmesi olarak tanımlanabilir (Akdemir, Çınar, \& Görgülü, 2007). Yaşlıların yaşadıkları en temel sorunlardan biri ayrımcılığa maruz kalmaktır. Yaşlılara yönelik sunulan hizmetlerin kalitesini de etkileyen yaş ayrımcılığı çeşitli sebeplerle bireylerin kaynak ve fırsatlara erişmesine engel olmaktadır. Yalnızca maddi kaynaklara erişememek bile başlı başına birçok şeyde yoksunluk yaşamaya zemin hazırlamaktadır. Yaşlılık beraberinde yaşlılara yönelik birçok ayrımcı davranışı getirdiği için toplumdan dışlanma sorunları yaşayan yaşlılar bir de yoksullaşarak sorunların yıkıcı etkileri daha da artmaktadır. Yaş ayrımcılığı özellikle üretimde rol alma ve istihdama katılmada yaşlı bireyleri dezavantajlı duruma düşürmektedir (Artan \& Taşçı, 2018). Ayrımcı davranışlar yaşlıları temel hizmetlere ulaşmada dışlanma, toplumsal tüketim mallarından dişlanma, finansal üretimden dişlanma, sosyal ve kültürel aktivitelerden dişlanma gibi sosyal yaşamın parçası olan aktivitelerden uzaklaştırır (Kalınkara, 2016). Bireylere ekonomik gelir kaynağı olan çalışma yaşamında yaşlılara yönelik ayrımcı davranışların açıkça uygulandığ bilinmektedir. İşe alımlar için konan yaş sınırları, dijital teknolojilere adapte olamayacakları nedeniyle işe kabullerinin yapılmaması, mesleki yeterlilik için donanımlı olmadıkları gibi genel düşüncelerle yaşlıların gelir elde etmesine engel olunduğu görülmektedir. Alınan 
ücretler açısından değerlendirildiğinde de yaşlılar gençlere göre daha düşük ücretleri kabul etmek durumunda kalmaktadırlar. Yaşlıların çalıştıkları iş yerlerinde kendisinden daha genç olanlara göre işten çıkarılma ihtimalleri de daha yüksektir ve iş akdine son verilecek ilk kesim olarak görülürler (Topgül, 2016).

\section{Sosyal İzolasyon ve Yalnızlık}

Yaşlanma ile ilgili yapılan çalışmalarda üzerinde hem fikir olunan konulardan biri yaşlılık ile yalnızlık ve sosyal izolasyon arasındaki ilişkinin varlığıdır. Yaşla birlikte çocukların evden ayrılması, ölümler, kayıplar gibi nedenlerle azalan ilişkiler ağı yalnızlık ve izolasyon durumunu yaratmaktadır (Şentürk, 2018). Günümüzde yaşlıların en birincil sorunları arasında ekonomik güvence yoksunluğu, barınmaya ilişkin sorunlar ve yalnızlık yer almaktadır. Geniş ailelerin yerini çekirdek aileye bırakmasıyla yaşlının ailesinden alabildiği sosyal destek düzeyi azalmıştır ve yalnızlık bu dönemde üzerinde dikkatle durulması gereken bir olgu haline gelmiştir. Geleneksel aile modellerinde dahi yalnızlık, sosyal izolasyon ve bunlarla ilişkili yoksulluk gün geçtikçe çözümlenmesi güç görevler haline dönüşmüştür. Yaşlının ekonomik koşullarının yalnızlık ve sosyal izolasyon üzerinde etkili olduğu çeşitli çalışmaların konusu olmakla birlikte sosyal ilişkilerin sürdürülmesinin yaşlılar için hayati öneme sahip olduğu vurgulanmıştır. Yoksulluk bir bakıma yaşlıların izole olmasında ve yalnızlaşmasında en önemli belirleyici durumundadır. Temel ihtiyaçlarını karşılamakta zorlanan yaşlılar sosyal ilişkilerini sürdürebilmek için yeterli gelire sahip değillerdir. Bu durum yaşlıların toplumsal hayatla olan bağlarını sınırlandırmaktadır. Gündelik hayatın içinde aktif yer alma araçları olan sosyal kültürel faaliyetlere katılmak maddi kaynak varlığ ile yakından ilişkilidir. Bu nedenle maddi yoksunluk içerisinde olan bireylerin toplumdan izole ve tek başlarına hayatlarını idame ettirme çabaları olağandır (Danış, 2007).

Ülkemizde yoksullaşan, yalnız kalan ve sosyal hayattan izole olan yaşlıların kendi kendilerine yetememeleri ve yaşamlarını idame ettirememeleri nedeniyle çeşitli sosyal, kültürel ve maddi sorunlar yaşadıkları bilinmektedir. Sosyal hizmet uzmanları yaşlı bireylerin ihtiyaçlarını biyo psiko sosyal bakış açısıyla değerlendirerek sosyal iyilik halini engelleyen durumların ortadan kaldırılması için görev almaktadır. Sosyal hizmet müdahalelerinde yalnızlık ve sosyal izolasyonun yoksulluk olgusu üzerinde derinleştirici etkisi üzerinde sıkça durulmaktadır ve alternatif çözüm yolları geliştirilmeye çalışılmaktadır. Yoksulluk, sosyal izolasyon ve yalnızlıkla ilişkili problemlerin çözümü için sosyal hizmet perspektifli politika ve uygulamaların geliştirilmesi, yaşlılar için sosyal kültürel sermayenin attırılması, yaşlı odaklı sosyal alanların düzenlenmesi, genç nesil ve yaşlı nesil arasındaki bağları güçlendirici sosyal organizasyonların planlanması, yaşlının aile ve yakın çevresi ile ilişkilerinin iyileştirilmesi, yaşlının yapabilirliği ölçüsünde istihdamdaki yerinin sürdürülmesi bu müdahalelere örnek olarak verilebilir.

Kaliteli ve aktif yaşlanma süreçlerini yaşlılara yaşatabilmek için günümüz toplumunda yaş ayrımcılı̆̆ı ile mücadele zorunlu hale gelmiştir. Sosyal hizmet mesleği toplumsal yaşamda ayrımcılık ve baskının her çeşidi ile mücadele eden bir meslek grubudur. Yaş ayrımcılığının ortadan kaldırılması için atılacak her türlü mesleki adım yaşlılara yönelik sunulan sosyal hizmetlerin nihai amaçlarındandır. Sosyal hizmet uzmanları yaşlılık döneminde kariyer planlamaları, dijital teknolojilerin yaşlılara uygun tasarlanabilmesi, yaşlının teknolojiye uyum sürecinin desteklenmesi, çalışma yaşamında yaşlının emeğinin istismar edilmesine yönelik 
hak savunuculuğu, sosyal medya, televizyon gibi araçlarda yaşlılara ilişkin damgalayıcı söylemler gibi çeşitli perspektiflerde yaş ayrımcılı̆̆ ile mücadele etmelidirler. Olumlu yaşlılık algısı oluşturmaya yönelik farkındalık oluşturmak için sosyal hizmetler, sağlık, sosyal güvenlik, sosyal politika alanlarında çalışan profesyoneller bir arada çalışarak toplumsal eğitimler düzenlemelidir. Yaşlılar toplumda fiziksel ve ruhsal becerileri ile uyumlu sosyal ve ekonomik alanlara aktif olarak katılabilecek bir nüfus grubudur. Bu nedenle ayrımcılığa maruz bırakılarak dışlanmaları ve yoksulluk yaşamlarının önlenmesi için makro düzeyde politikaların geliştirilmesi gerekmektedir.

\section{Sonuç}

Yoksulluk geçmişten günümüze her dönem hemen her ülkede varlığını sürdüren sosyal bir sorundur. Hem nedenleri hem de sonuçlarıla çok boyutlu olan yoksulluk olgusu bireylerin hayatındaki pek çok alanda olumsuz etkiler yaratabilmektedir. Dünya üzerinde yaşam sürelerinin uzamasıyla sayısı gün geçtikçe artan yaşlı nüfusun sorunları ve ihtiyaçları da giderek karmaşıklaşmaktadır. Yoksullukta bir sorun alanı olarak yaşlılık deneyimlerini kötü yönde etkileyerek yaşlıların bireysel, psikolojik ve sosyal iyilik hallerini tehdit etmektedir. Yaşlılıkta pek çok yeni duruma uyum sağlamaya çalışan bireyler bir de yoksullukla karşı karşıya kaldıklarında sorunları daha da ağırlaşmaktadır. Sosyal hizmet mesleği doğuşundan itibaren yoksullukla mücadele eden akademik disiplinlerin başında gelmiştir. Sosyal hizmet uzmanları bir ülkede kaynak ve fırsatların eşit bir şekilde dağıtılması, yoksulluğun azaltılması ve önlenmesi, yoksul kişilerin sağllk, eğitim, istihdam, sosyal kültürel olanaklara erişmesini sağlama gibi mikro düzeyden makro düzeye yoksulluk olgusu ile çalışmaktadırlar. Sosyal hizmet mesleği için yoksulluğa neden olan etmenlerin riskleriyle birlikte saptanması, sorun analizini doğru yapabilmek müdahale ve uygulama geliştirmek için oldukça önemlidir. Bu çalışmada yaşlı yoksulluğuna ilişkin risk etmenleri fizyolojik değişimler, toplumsal cinsiyet, istihdam, sosyal yardımlar, ayrımcılık, sosyal izolasyon ve yalnızlık olarak ele alınmıştır. Sosyal hizmet uygulamasının nihai amacı bireylerin hayatlarını kendi kendilerine idame ettirecek düzeye gelmeleri için özgürleşmelerini ve güçlenmelerini sağlamayı sağlamaktır. Bu çalışmada yaşlı yoksulluk ile mücadeleye ilişkin sunulan önerilerin sosyal hizmet mesleğinin amaçları ile paralel olduğu söylenebilir.

\section{Kaynakça}

Aile, Ç. v. S. H. B. (2019). Türkiye Aile Yapısı Araştırması, 2016. In (pp. 198-199). Ankara: TDV Yayın Matbaacılık ve Ticaret İşletmesi.

Aile, Ç. v. S. H. B. (2021). Sosyal Yardım Programlarımız. Retrieved from https://ailevecalisma.gov.tr/sygm/programlarimiz/sosyal-yardim-programlarimiz/

Akdemir, N., Çınar, F. İ., \& Görgülü, Ü. (2007). Yaşlılığın algılanması ve yaşlı ayrımcılı̆̆ı. Türk Geriatri Dergisi, 10(4), 215-222.

Artan, T., \& Taşçı, A. (2018). İş piyasasında yaş(lı) ayrımcılı̆̆ı. Journal of Social And Humanities Sciences Research, 5(25), 2413-2421.

Beğer, T., \& Yavuzer, H. (2012). Yaşlılık ve yaşlılık epidemiyolojisi. Klinik gelişim, 25(3), 1-3. 
Buz, S. (2015). Toplumsal cinsiyet ve yoksulluk odağında yaşlılık olgusu. Hacettepe Üniversitesi Sosyolojik Araştırmalar E Dergisi, 1-10. Retrieved from http://www.sdergi.hacettepe.edu.tr/?page=makaleler

Danış, M. Z. (2007). Yaşlılık, yoksulluk ve yalnızlık. Retrieved from http://www.gebam.hacettepe.edu.tr/sosyal boyut/yaslilik_yoksuluk_yanlizlik.pdf

Danış, M. Z. (2009). Türkiye' de yaşlı nüfusun yalnızlık ve yoksulluk durumları ve sosyal hizmet uygulamaları açısından bazı çıkarımlar. Toplum ve Sosyal Hizmet Dergisi, 20(1), 67-83.

Ensari, S. (2010). TÜİK'in yoksulluk analizleri üzerine. Maliye ve Finans Yazıları Dergisi, 1(87), 9-15.

İçağasıŏlu Çoban, A. (2014). Yoksullukla mücadelede sosyal hizmetin rolü. In G. Polat \& A. İçağasıŏlu Çoban (Eds.), Yoksulluk ve Sosyal Hizmet (pp. 11-26). İstanbul: Sosyal Çalışma Yayınları.

İştar, C. (2018). Türk sosyal güvenlik sistemi içerisinde yaşlılara yönelik sosyal yardım ve sosyal hizmetler. SGD-Sosyal Güvenlik Dergisi, 8(2), 23-40.

Kalınkara, V. (2016). Yaşlılık: Disiplinlerarası Yaklaşım, Sorunlar, Çözümler 2. Ankara: Nobel Akademik Yayıncllık Eğitim ve Danışmanlık Tic. Limited Şti.

Kalınkara, V., Argun, N., \& Güler, P. (2014). Temel Gerontoloji: Yaşlılık Bilimi. Ankara: Nobel Akademik Yayıncılık Eğitim ve Danışmanlık Tic. Limited Şti.

Kalkınma Bakanlığı. (2013). Onuncu Kalkınma Planı 2014-2018. In (pp. 51-54). Ankara: Kalkınma Bakanlığ 1 .

Karadeniz, O., \& Öztepe, N. D. (2013). Türkiye'de yaşlı yoksulluğu. Çalışma ve Toplum Dergisi, $38(3), 77-102$.

Karakuş, B. (2019). Türkiye'de yaşlılara yönelik hizmetler ile bu hizmetlere ilişkin kuramsal yapı ve mevzuat: Aile Çalışma ve Sosyal Hizmetler Bakanlığının yaşlılara yönelik hizmetleri. In U. Yanardağ \& M. Zubaroğlu Yanardağ (Eds.), Yaşlılık ve Sosyal Hizmet (pp. 263-305). Ankara: Nika Yayınevi.

Karatas, S. A., \& Durmaz, H. (2017). Yaşlılık donemi psikolojik özellikleri ve moral. Kocatepe Tip Dergisi, 18(1), 32-36.

Kurt, G., Beyaztaş, F. Y., \& Erkol, Z. (2010). Yaşlıların sorunları ve yaşam memnuniyeti. Adli Tip Dergisi, 24(2), 32-39.

Mandıracıoğlu, A. (2010). Dünyada ve Türkiye'de yaşlıların demografik özellikleri. Ege Tıp Dergisi, 49(3), 39-45.

Metin, B. (2014). Yoksullukla mücadeleye insan hakları açısından bakmak: Amartya Sen'in kapasite (capability) yaklaşımı temelinde bir değerlendirme. Journal of Yasar University, 9(36), 6315 - 6327.

Muammer, A., \& Közleme, O. (2017). Yaşl1 yoksulluğu. Ahi Evran Üniversitesi Sosyal Bilimler Enstitüsü Dergisi, 3(2), 197-208.

Nazlıer Keser, E. N. (2019). Türkiye'de yaşlı yoksulluğu sorununa yönelik bir değerlendirme. Toplum ve Sosyal Hizmet Dergisi, 30(2), 739-764. 
Ofluoğlu, G., \& Özbucak Albar, B. (2017). Yaşlı işgücünün iş sağllğı ve iş güvenliği sorunları ve çözüm önerileri. Hak İş Uluslararası Emek ve Toplum Dergisi, 6(15), 335-360.

Özen, S., \& Özbek, Ç. (2017). Çalışma yaşamında yaşlılık: Yaşlı çalışanlar ve insan kaynakları uygulamaları. Çalışma ve Toplum Dergisi, 53(2), 547-572.

Stoller, M. A., \& Stoller, E. P. (2003). Perceived income adequacy among elderly retirees. Journal of Applied Gerontology, 22(2), 230-251.

Şentürk, Ü. (2018). Yaşlılık Sosyolojisi Yaşlılığın Toplumsal Yörüngeleri. Bursa: Dora Yayıncılık.

Taş, H. Y., \& Özcan, S. (2012). Türkiye'de ve Dünya'da yoksulluk üzerine bir araştırma. Paper presented at the International Conference on Eurasian Economies.

Tekindal, M. (2019). Gelişimsel özellikleri açısıdan yaşlıyı değerlendirme. In U. Yanardağ \& M. Zubaroğlu Yanardağ (Eds.), Yaşlılık ve Sosyal Hizmet (pp. 67-80). Ankara: Nika Yayınevi.

Topgül, S. (2016). Çalışma yaşamında yaşlı ayrımcılığı mı yaş ayrımcılığı mı? Sosyoloji Dergisi, $36(2), 373-391$.

TÜIKK. (2020). İstatistiklerle Yaşlılar, 2019. Retrieved from https://data.tuik.gov.tr/Bulten/Index?p=Istatistiklerle-Yaslilar-2019-33712

Uzun, A. M. (2001). Yoksulluk olgusu ve Dünya Bankası. Çukurova Üniversitesi İktisadi ve İdari Bilimler Fakültesi Dergisi, 4(2), 155.174.

Yerli, G. (2017). Yaş̧lılık dönemi özellikleri ve yaşlılara yönelik sosyal hizmetler. Uluslararası Sosyal Araştırmalar Dergisi, 10(52), 278-1287.

Yumurtacı, A. (2013). Demografik değişim: Psiko sosyal ve sosyo ekonomik boyutlarıyla yaşlılık. Yalova Üniversitesi Sosyal Bilimler Dergisi, 3(6), 9-31.

Zengin, E., Şahin, A., \& Özcan, S. (2012). Türkiye'de sosyal yardım uygulamaları. Yönetim ve Ekonomi Dergisi, 19(2), 133-142. 